\title{
Pertimbangan Konsumen Memilih Provider Telkomsel Daripada Indosat, $\mathrm{XL}$ (Penerapan Teori Uses And Gratifications Magister Unitomo)
}

\author{
${ }^{1}$ Fitrianingsih, ${ }^{2}$ M. Alfin Fatikh \\ ${ }^{1}$ Universitas Dr. Soetomo, ${ }^{2}$ Institut Pesantren KH. Abdul Chalim Pasuruan \\ ${ }^{1}$ fitrianingsih.mikom@gmail.com, ${ }^{2}$ Muhammad.alfinfatikh@gmail.com
}

\begin{abstract}
ABSTRAK
Untuk saat ini masyarakat Indonesia adalah masyarakat yang berada dalam kondisi peralihan berkembang dari masyarakat agraris yang penuh dengan spiritualistik menjadi masyarakat industri modern yang materialistis. Bahkan mereka memiliki tindakan pribadi yang berbeda untuk berkomunikasi atau bersosialisasi. Bersosialisasi dapat dilakukan dengan menggunakan media sosial. Sebagai contoh di media telekomunikasi, Telepon yang pada awalnya merupakan media statistik yang berubah menjadi lebih baik, lebih pintar, lebih mudah dengan handphone untuk akses internet. Untuk koneksi ke internet, pada handphone tentunya kita membutuhkan provider yang memiliki koneksi data internet. Untuk pengalaman data internet Periset menggunakan 3 provider yaitu Telkomsel, Indosat dan XL. Telkomsel, Indosat dan XL merupakan beberapa operator perusahaan telekomunikasi di Indonesia. Tapi yang membuatnya berbeda adalah harga, kualitas dan sinyal. Untuk pemeriksaan sinyal kita dapat melihatnya dari BTS (Base Transceiver Station) dan untuk teori yang digunakan untuk analisis Penelitian ini yang telah dipilih oleh peneliti adalah Teori Uses and Gratifications.
\end{abstract}

\section{Kata kunci: Pertimbangan, Konsumen, Provider}

\section{ABSTRACT}

Indonesia citizenship nowdays is a citizens who are in transitional condition which is growing up from agraris citizenship who full with spiritualistic become modern industrial citizenship who materialistic. Even they have different personal act to communicate or socialize. The socialitation we can be using a social media. For the example in media telecommunication. Telephone which at the start were statistic media changes to be better, smarter, easier with mobile to reach the internet. To connect to internet mobile of course we need a provider who has internet data connection. For the experience of internet data researchers are using 3 providers which is Telkomsel, Indosat and XL. Telkomsel, Indosat and XL some of celluler telecomunication company operator in Indonesia. But the one which make it different is price, quality and signal. For the signal check we can see it from BTS (Base Transceiver Station) and for theory that been used for analysis of this researchers which have been choosen by the researchers is Uses and Gratifications Theory.

Keywords: Considerations, Consumers, Providers 


\section{PENDAHULUAN}

Masyarakat terus bergerak dan tumbuh dari masyarkat tradisional menuju masyarkat modern, hal ini dibenarkan dengan mengutip pendapat Vinna Sri Yuniarti (Perilaku Konsumen Teori dan Praktek, 2015: 17) menjelaskan saat ini masyarakat Indonesia berubah dan berkembang dari masyarakat yang sedang berada dalam keadaan transisional yakni bergerak dari masyarakat agraris tradisional yang penuh dengan suasana spiritualistik menuju masyarakat industri modern yang materealistik. Sehingga menurut Vinna dalam terminologi tersebut ia menjelaskan bahwa keadaan Indonesia ini dikategorikan sebagai masyarakat yang sedang bergerak dari bentuk masyarakat yang penuh solidaritas organik. Dalam kondisi inilah dimungkinkan akan muncul fenomena kegalauan budaya pada tingkat individu dan tingkat sosial.

Tuntutan zaman seperti yang disampaikan oleh Vinna (2015; 19) menitikberatkan pada zaman yang semakin maju mau tidak mau menyebabkan masyarakat juga turut berpartisipasi/mengikuti. Karena asumsi publik menyatakan jika orang tidak mengikuti trendsetter, maka ia akan dianggap katrok atau ketinggalan zaman. Hal itulah yang membuat masyarakat saat ini mau tidak mau harus mengikuti kemajuan dan perkembangan teknologi dan komunikasi. Para pakar dan praktisi teknologi informasi sudah sepakat, bahwa sekarang dan masa yang akan datang adalah era perangkat mobile. (Thomas Joseph, Apps The Spirit of Digital Marketing 3.0, 2002: 128)

Berbicara mengenai perkembangan teknologi dan komunikasi, dengan teknologi mobile (handphone), konsumen dapat melakukan aktivitas apa saja, mulai dari chatting, perbankan, pesan barang, sampai berjejaring sosial. Biaya telekomunikasi dapat menjadi lebih murah dan setiap orang menjadi lebih terakses. Dampaknya antara lain dapat dilihat dari memudarnya usaha wartel dan warnet yang sempat booming beberapa waktu yang lalu. Nurudin, Sistem Komunikasi Indonesia (2010:187).

Income dan teknologi telah berubah, demikian pulalah perilaku dan gaya hidup. Dalam telekomunikasi, telepon yang semula statis berubah menjadi mobile dan pergi mengikuti kaki melangkah. Telepon seluler tak hanya digunakan untuk menelpon tetapi juga untuk berkirim SMS (Short Message Service) dan foto. Ponsel kemudian menjadi (lebih) cerdas dan dengan mudah terhubung ke Internet. Dapat dilakukan mengirim dan menerima surel (surat elektronik). Memudahkan terjadinya sosial media atau jejaring sosial. Untuk terkoneksi ke jejaring sosial atau jaringan Internet pada mobile tentu diperlukan provider yang menyediakan kuota data. Untuk kuota data pada penelitian ini menggunakan 3 provider yaitu Telkomsel, Indosat dan juga XL. Tiga provider tersebut dipilih karena menempati posisi provider yang paling banyak dipergunakan oleh konsumen. Menurut pendapat Prof. Rhenald Kasali, Ph.D. posisi tiga besar operator ponsel pada tahun 2006 adalah sebagai berikut: 
3 - $\begin{aligned} & \text { p-ISSN 2723-4703 } \\ & \text { e-ISSN 2797-1619 } \\ & \text { http://ejurnal.iaipd-nganjuk.ac.id/index.php/j-kis/ } \\ & \text { KURNALUNIKASI ISLAM }\end{aligned}$

Operator Jumlah Pelanggan Q2 (2006)

\begin{tabular}{l|l|} 
Telkomsel & 29,3 Juta $(56,8 \%)^{* * *}$ \\
Indosat & 13,9 Juta $(26,9 \%)^{* * *}$ \\
XL & 8,4 Juta $(16,3 \%)^{* * * *}$ \\
Total 3 Besar & 51,6 Juta $(100 \%)$ \\
\cline { 2 - 3 }
\end{tabular}

Tabel 1.1 Posisi Tiga Besar Operator Ponsel oleh Prof. Rhenald Kasali, Ph.D.

Keterangan:

* $\quad$ Kuartal ke-2 tahun 2006

** Telkomsel (Juli 2006). Laporan Keuangan (Unaudited) Kuartal ke-2, 2006

*** $\quad$ PT Indosat Tbk. (Juni 2006). Ikhtisar Laporan Keuangan

Kuartal Ke-2, 2006

**** PT Excelcomindo Pratama Tbk. (Juni 2006). Laporan Pertumbuhan

Pendapatan Kuartal Ke-2, 2006.

Untuk update jumlah pengguna Telkomsel, Indosat dan XL tahun 2014 dapat diihat pada tabel dibawah ini:

Operator Seluler

Telkomsel
XL Axiata
Indosat

Pengguna Q1

\begin{tabular}{|cc|}
\hline 132,7 Juta & 139,2 Juta \\
\hline 62,9 Juta & 58,3 Juta \\
69,7 Juta & 54,3 Juta \\
\hline
\end{tabular}

Tabel 1.2 Jumlah Pengguna Provider Telkomsel, Indosat dan XL Sumber dari situs id.techinasia.com dan ditulis oleh Ketut Krisna Wijaya, tgl 25 November 2014

Sumber dari teknoliputan6.com dapat dilihat dibawah ini daftar paket dari tiga provider, yaitu Telkomsel, Indosat dan juga XL Axiata sebagai perbandingan harga dan jumlah kuota yang didapatkan konsumen adalah sebagai berikut:

\begin{tabular}{|llll|}
\hline No & \multicolumn{1}{c}{$\begin{array}{c}\text { Telkomsel } \\
\text { (Simpati) }\end{array}$} & \multicolumn{1}{c|}{$\begin{array}{c}\text { Indosat } \\
\text { (Freedom Combo) }\end{array}$} & $\begin{array}{c}\text { XL Axiata } \\
\text { (XTRA Combo) }\end{array}$ \\
\hline 1 & $\begin{array}{c}47.500 .-/ 30 \text { hari } \\
\text { 59.000.-/30 hari }\end{array}$ & $59.000 .-/ 30$ hari \\
\hline 2 & Flash 3G (1GB) & 24 jam kuota 3G (2GB) & 24 jam kuota 3G (2GB) \\
\hline 3 & $\begin{array}{l}\text { Flash 00-07 MDS } \\
\text { 2GB }\end{array}$ & 24 jam kuota 4G (3GB) & 24 jam kuota 4G (4GB) \\
\hline 4 & HOOQ+VIU/30 & Free Spotify bulan 1st & 24 jam kuota Youtobe \\
\hline
\end{tabular}


Pertimbangan Konsumen Memilih Provider Telkomsel Daripada Indosat, XL (Penerapan Teori Uses And Gratifications Magister Unitomo)

\begin{tabular}{|llll|}
\hline & hari & & $(2 \mathrm{~GB})$ \\
\hline 5 & Video Max 1GB & $\begin{array}{l}\text { Free 1GB kuota Stream On 10 } \\
\text { Apps On }\end{array}$ & $\begin{array}{l}01.00-06.00 \text { WIB kuota } \\
\text { Youtobe Unlimited }\end{array}$ \\
\hline 6 & - & - & Nelpon all opr 20" \\
\hline 7 & - & Akses aplikasi populer & Gratis berlangganan \\
& & TANPA KUOTA dengan & $\begin{array}{l}\text { Genfix, Yonder, } \\
\text { Tribe/30 hari }\end{array}$ \\
\hline
\end{tabular}

Tabel 1.3 Perbandingan Harga dan Fitur Tiga Provider yaitu Telkomsel, Indosat dan XL. Sumber: teknoliputan6.com

Tanggal 28 April 2017, peneliti mendapatkan beberapa informasi terkait dengan Web dari Telkomsel yang diretas oleh Hecker. Hecker tersebut komplain mengenai harga dari kuota Telkomsel yang dikatakan mahal karena perbandingan harga dapat dilihat pada tabel diatas. Untuk jumlah kuota yang didapatkan lebih sedikit, tidak sebanding dengan harga yang ditawarkan oleh para pesaingnya dan respons masyarakat terkait dari kasus tersebut bermacam-macam. Baik itu mendukung aksi hacker dan ada pula yang mendukung Telkomsel. Untuk meneliti pertimbangan konsumen memilih Provider Telkomsel daripada Indosat dan XL adalah dengan menggunakan teori Uses and Gratifications dan teori SOR. Teori Uses and Gratifications lebih menekankan pada pendekatan manusiawi dalam melihat media massa dan teori S-O-R adalah Stimulus-Organism-Respon yang melihat pada komponen-komponen sikap, opini, perilaku, kognisi, afeksi, konasi yang menjadi acuan dari penelitian tersebut.

\section{METODE PENELITIAN}

Metode penelitian yang dipergunakan oleh peneliti adalah case study (studi kasus). Mengutip pendapat Drs. Cholid Narbuko dan Drs. H. Abu Achmadi (2009: 46) menjelaskan bahwa ciri-ciri penelitian kasus merupakan penelelitian yang mendalam mengenai kasus tertentu yang hasilnya adalah gambaran lengkap dan terorganim mengenai para Informan dalam mempertimbangkan dalam memilih menggunakan provider Telkomsel dibandingkan dengan menggunakan provider Indosat dan juga XL. Karna itulah peneliti menggunakan penelitian kualitatif dengan pola deskriptif. Peneliti lebih memfokuskan kualitas penelitian dengan cara melakukan pendalaman dari kasus tersebut. Berdasarkan latar belakang masalah dan tujuan penelitian perlu adanya sebuah batasan di dalam melakukan penelitian ini agar tidak melebar. Maka dari itu peneliti membuat fokus penelitian sebagai berikut: Penelitian ini ada pada bidang komunikasi massa yang lebih fokus kepada komunikan yang menerima pesan dari media massa, Objek penelitian mengenai pertimbangan konsumen memilih provider Telkomsel daripada Indosat dan XL. Sehingga peneliti menggunakan 2 informan dari 19 Informan yaitu mahasiswa 
Universitas DR. Soetomo Gedung H lantai IV J1. Semolowaru 84, Surabaya 60118, Program Studi Magister Ilmu Komunikasi dengan minat studi Public Relations mahasiswa semester 3 .

Sumber data yang digunakan ada 2 macam yaitu sumber data primer dan sumber data sekunder. Mengutip pendapat Lofland dan Lofland (1984: 47) yang dituliskan oleh Dr. Lexy J. Moeleong M.A. pada buku Metodologi Penelitian Kualitatif (2002: 112) menjelaskan bahwa sumber data utama (primer) dalam penelitian kualitatif ialah kata-kata dan tindakan Maria Magdalena dan Fauziyah sebagai informan dan selebihnya adalah data tambahan (sekunder) seperti dokumen dan lain-lain.

\section{HASIL DAN PEMBAHASAN}

Pada gambaran objek penelitian ini, peneliti menjelaskan lebih lanjut terkait dengan tiga provider yang digunakan oleh konsumen. Tiga provider itu dipilih karena merupakan provider dengan jumlah terbanyak untuk pengguna di Indonesia. Provider itu ang peneliti maksudkan terdiri dari Telkomsel, Indosat dan juga XL. Untuk perbandingan harga serta jumlah kuota yang didapatkan sudah peneliti bahas pada latar belakang dan hal menarik lainnya adalah mengenai Apa yang menjadi keistimewaan provider telkomsel, padahal telah diketahui sebelumnya bahwa harga dan kuota sangat jauh berbeda dengan para pesaingnya. Akan tetapi dengan melihat tabel jumlah pengguna provider pada tahun 2014 yang diambil oleh peneliti menjelaskan produk Telkomsel masih menempati urutan pertama dengan jumlah pengguna pada Quartal pertama ada 132,7 Juta pengguna dan untuk Quartal ketiga mengalami kenaikan dengan jumlah pengguna sebesar 139,2 Juta. Untuk provider kedua ditempati oleh XL Axiata dengan jumlah pengguna pada Quartal pertama sebanyak 62,9 Juta, lalu naik pada Quartal ketiga menjadi 58,3 Juta pengguna. Dan untuk provider terakhir ditempati oleh Indosat dengan jumlah pengguna sebanyak 69,7 Juta dan untuk Quartal ketiga sebanyak 54,3 Juta pengguna.

Untuk Indosat dan XL pada Quartal kedua tahun 2006 data yang diambil oleh Prof. Rhenald Kasali, Ph.D. menjelaskan bahwa Indosat dan XL saling kejar mengejar dalam hal menempati posisi kedua dan ketiga karena untuk jumlah pengguna Indosat ada sebanyak 13,9 Juta sedangkan XL ada sebanyak 8,4 Juta pengguna. Sedangkan untuk Telkomsel masih menempati urutan pertama dengan jumlah pengguna 29,3 Juta. Meskipun sumber ini didapatkan baik itu dari tahun 2006 dan tahun 2014, pada tahun-tahun tersebut menjelaskan bahwa Telkomsel adalah provider yang paling banyak diminati oleh pengguna provider di tanah air meskipun harga yang ditawarkan berbeda dengan provider Indosat dan juga XL.

Untuk temuan data di lapangan, peneliti akan menjelaskan beberapa hal yaitu sebagai berikut: 
1. Konsumen berperilaku sebagai respon yang rutin

Pada tingkat ini, kedua pengguna provider baik itu Maria Madalena dan Fauziyah sudah mempunyai pengalaman mengenai ketegori produk dan serangkaian keriteria yang mereka tetapkan dengan baik untuk menilai berbagai merek yang mereka gunakan. Dalam beberapa situasi informan kemungkinan mencari informasi tambahan dan dalam situasi lain mereka hanya meninjau kembali apa yang sudah mereka ketahui mengenai provider yang mereka gunakan saat ini. Seberapa mendalam tugas pemecahan masalah mereka bergantung pada seberapa baik kriteria pemilihan yang telah mereka tetapkan, seberapa banyak informasi yang telah dimiliki mengenai provider yang mereka jadikan pertimbangkan dan seberapa terbatas rangkaian merek yang akan dipilih. Jelas bahwa untuk pemecahan masalah yang luas. Kedua informan harus mencari informasi yang lebih banyak untuk melakukan pilihan jika mereka menjadi konsumen yang tidak rutin menggunakan provider atau tidak loyal pada merek tersebut. Akan tetapi, informasi yang telah didapat menunjukkan bahwa ke dua informan baik Maria Magdalena dan Fauziyah memiliki perilaku respon yang rutin. Dimana, mereka hanya memerlukan sedikit informasi tambahan yang diperlukan.

2. Distribusi dan strategi pemasaran Telkomsel

Dari situs resmi Telkomsel (http://www.telkomsel.com) Telkomsel Perluas Saluran Distribusi Layanan Menggandeng E-Commerce. Jakarta, 22 Desember 2016 - Telkomsel menggandeng 14 perusahaan e-commerce ternama di Indonesia untuk memperluas jaringan distribusi layanan. Kerjasama ini akan membuat pelanggan lebih mudah untuk memperoleh layanan Telkomsel melalui saluran daring (online channel) yang dimiliki Tokopedia, Kaskus, Alfacart, Blanja, Lazada, Go-Jek, Mataharimall, Traveloka, Bhinneka, Blibli, JD.id, Grab, Bukalapak, dan Dinomarket.

3. Distribusi dan strategi pemasaran Indosat

Bersumber dari (http://seemewendy.blogspot.co.id/p/blogpage_75.html) blog online yang ditulis oleh Wendy Ariesta menjelaskan bahwa Indosat memasarkan produk dan jasa selular dengan cara pemasaran langsung dan juga melalui agen penjualan. Persentase terbesar pendapatan usaha selular berasal dari agen-agen penjualan dalam kemitraan yang saling menguntungkan. Menurut Wendy Indosat ini memiliki lebih dari 325.000 Points of Sale (POS) yang dapat dibagi menjadi 280.000 outlet tradisional, lebih dari separuhnya bergabung dalam komunitas outlet Indosat; outlet modern dan perbankan yang terdiri dari 14.000 outlet retail modern seperti Indomaret, Alfamart, Carrefour, dsb, plus 30.000 POS berupa ATM bank; dan berbagai pusat penjualan dan layanan pelanggan terpadu yang dinamakan Galeri Indosat, Griya Indosat, dan KILAT. Wendy juga menjabarkan beberapa POS dari Indosat yang terdiri dari Galeri Indosat dikelola oleh Indosat, Griya Indosat dimiliki oleh agen 


\section{J-KIs

penjualan, sedangkan KILAT (Indosat Sales \& Service Kiosk) dimiliki dan dikelola oleh mitra perorangan Indosat. Pada akhir tahun 2011 tercatat 150 Galeri Indosat, 44 Griya Indosat dan 81 KILAT.

4. Distribusi dan strategi pemasaran XL

Dari situs (https://www.xl.co.id/business/id/mengapa-xl/tentang.html) dari blog resmi dari XL Axiata menjelaskan bahwa XL Axiata berfokus pada 2 aspek bisnis utama, yaitu Consumer Solutions, yang ditujukan untuk pelayanan telepon seluler berkualitas tinggi dan Business Solutions yang ditujukan untuk penyediaan solusi data dan komunikasi yang sangat efisien dan terpercaya untuk pasar korporat. Pada blog resmi XL Axiata tersebut dapat diketahui bahwa XL Axiata mengawali tahun 2015 dengan dimulainya strategi baru dalam arah bisnis melalui implementasi Agenda Transformasi XL yang disebut dengan "3R Strategy", yaitu:

a) XL Axiata mengubah model bisnis pencapaian jumlah pelanggan (dari "volume" ke "value"), strategi distribusi serta meningkatkan profitabilitas produk.

b) Dari blog resmi XL Axiata dapat diketahui bahwa mereka akan lebih fokus kepada peningkatan nilai brand XL dengan menggunakan dan melalui strategi dual- brand dengan AXIS untuk menyasar segmen pasar yang berbeda.

c) XL Axiata Membangun dan menumbuhkan berbagai inovasi-inovasi bisnis.

5. Loyalitas Konsumen

Vinna Sri Yuniarti, S.E., M.M. (Perilaku Konsumen, 2015:242) mengutip pendapat Tjiptono (2002) menjelaskan enam indikator yang dapat digunakan untuk mengukur loyalitas konsumen, yaitu:

a) Pembelian ulang

b) Kebiasaan mengonsumsi merek tersebut

c) Selalu menyukai merek tersebut

d) Tetap memilih merek tersebut

e) Yakin bahwa merek tersebut yang terbaik

f) Merekomendasikan merek tersebut kepada orang lain

\section{Teori Uses and Gratifications dan SOR}

Nurudin (Pengantar Komunikasi Massa, 2007; 191-195) menjelaskan bahwa Herbert Blumer dan Elihu Katz adalah orang pertama yang memperkenalkan teori ini. Teori Uses and Gratifications (Kegunaan dan Kepuasan) ini dikenal pada tahun 1974 dalam bukunnya The Uses on Mass Communications: Current Perspective on Gratifivations Research. Teori Uses and Gratifications milik Blumer dan Katz ini mengatakan bahwa pengguna media memainkan peran aktif untuk memilih dan menggunakan media tersebut. Sehingga Nurudin pada teori 
tersebut lebih menekankan pada pengguna media adalah pihak yang aktif dalam proses komunikasi. Pengguna media berusaha untuk mencari sumber media yang paling baik untuk memenuhi kebutuhannya. Sedangkan Teori S-O-R adalah sebagai singkatan dari Stimulus-Organism-Respon, ini semua berasal dari psikologi. Mengutip pendapat Onong Uchajana Effendi (Ilmu Teori dan Filsafat Komunikasi, 2003: 255) yang menjelaskan mengenai teori SOR bahwa teori ini mendasarkan asumsi penyebab terjadinya perubahan perilaku tergantung kepada kualitas rangsangan (stimulus) yang berkomunikasi dengan organisme. Elemen-elemen dari model ini adalah pesan (stimulus), komunikan (organisme), efek (respon). Model SO-R dapat digambarkan sebagai berikut:

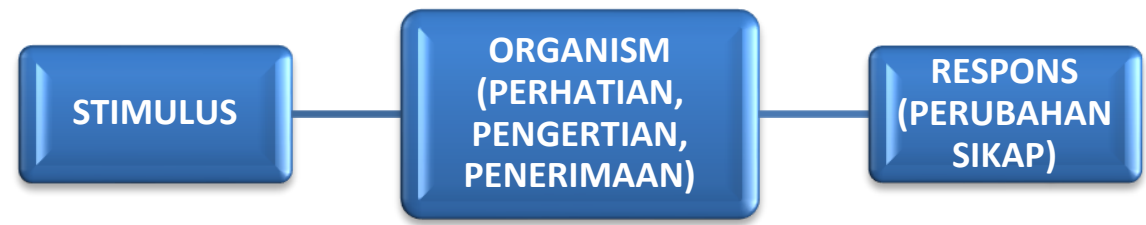

Bagan 1.1 Model SOR( Effendy, 2003:255)

Proses diatas mengambarkan perubahan sikap dan bergantung kepada proses yang terjadi pada individu. Menurut Dr. Saifuddin Azwar, M.A. (Sikap Manusia Teori dan Pengukurannya, 1995: 6) menjelaskan pendapat Petty \& Caciopo 1986 bahwa secara historis, istilah sikap (attitude) adalah evaluasi umum yang dibuat manusia terhadap dirinya sendiri, orang lain, objek, ataupun isu-isu.

Seperti yang telah diketahui sebelumnya bahwa komunikasi adalah penyampaian pesan oleh komunikator kepada komunikan. Jika membahas komunikasi itu sendiri menurut peneliti, maka peneliti menitikberatkan pada pemaknaan pesan yang diterima oleh komunikan. Untuk komunikator baik itu personal sampai ke komunikasi massa ketika pesan tersebut dapat diterima dan dapat dimaknai oleh komunikan maka komunikasi tersebut dapat peneliti katakan termasuk ke dalam kategori komunikasi yang efektif meskipun hanya bersifat satu arah (seperti analisa menggunakan teori jarum hipodermik) karena tidak adanya feedback (umpan balik ke media massa tersebut).

Jika diaplikasikan dalam menganilisa dan meneliti kedua informan baik itu Maria Magdalena dan Fauziyah maka kedua informan tersebut tidak sebegitu memanfaatkan informasi yang disampaikan oleh media massa seperti iklan hal ini dikarenakan peran gender yaitu kesibukan yang mereka lakukan. Yang dimaksudkan dengan peran gender disini adalah pengambilan tanggung jawab serta posisi dari kepala rumah tangga karna penelirian dari si peneliti ini adalah wanita. Maka lebih fokus pada kegiatan yang dilakukan oleh informan setiap harinya. Dari mulai peran ibu rumah tangga, mahasiswa, dan juga sebagai wanita karir. Karena penelitian ini bukan bersifat generalisasi seperti kuantiatif maka untuk peran gender tidak menjadi pembahasan lebih lanjut. Serta usia juga menjadi alasan kenapa 
penelitian ini memilih dua informan dengan batasan usia 35-54 tahun karena Schieffman dan Leslie (2008: 44) menjelaskan bahwa pada usia tersebut individu ketika menggunakan produk mereka cenderung hanya digunakan untuk menghilangkan atau mengatasi setress. Dan hal itu terbukti benar jika diterapkan kepada kedua informan. Bentuk hiburan yang dipilih oleh Maria magdalena dan juga fauziyah yaitu penggunaan sosial media (sosmed) seperti WhatsApp, Instagram, dll

Teori uses and gratifications ini melihat kedua informan sebagai pemilik kehendak bebas. Kedua informan menunjukkan kehendak bebas yang mereka miliki. Jika di kelompokkan dalam Pengelompokan psikografi maka pengelompokan ini bisa dilihat pada status sosial, gaya hidup dan kepribadian kedua informan tersebut. Menurut Drs. Ujam Jaenudin, M.Si. (Psikologi Kepribadian, 2012: 101) menjelaskan bahwa kepribadian adalah kesan yang diberikan seseorang kepada orang lain yang diperoleh dari sesuatu yang dipikirkan, dirasakan, diperbuat yang terungkap melalui perilaku seseorang. Sedangkan pengelompokan yang berkaitan dengan perilaku adalah mengelompokkan konsmen menurut frekuensi pembelian, manfaat produk, status pengguna, tingkat penggunaan, status kesetiaan. Sehingga peneliti dalam menganalisa informan melihat pesan dari media massa dapat berupa selective expossure, attentions, defense ataupun blocking. Akan tetapi karena faktor peran gender tersebut, lantas mereka mimilih tetap menggunakan provider telkomsel karena motif yang mereka miliki berupa kepuasaan koleksi nomer cantik untuk Maria Magdalena dan harga ekonomis serta kualitas signal dari provider Telkomsel untuk Fauziyah. Kedua informan sama-sama melakukan blocking iklan dari semua provider melalui media massa yang berupa televisi karena kesibukan mereka.

Untuk kedua informan pada tahap persepsi akan dapat diketahui dengan adanya stimulus (rangsangan) dari luar yang akan mempengaruhi proses dalam menentukan dan menggunakan kelima alat indera mereka, yaitu pengelihatan, pendengaran, penciuman, perasaan dan sentuhan. Stimulus tersebut diseleksi, diorganisasi, dan diinterpretasikan oleh diri mereka sendiri dengan cara masingmasing. Proses persepsi ini diawali dengan adanya stimuli yang mengenai panca indera yang disebut sensasi. Stimuli ini beragam bentuknya dan akan selalu memborbardir indera informan. Jika dilihat dari asalnya, stimuli pada konsumen ada yang berasal dari individu (seperti aroma, iklan, dan lain-lain) serta yang berasal dari dalam diri individu, seperti harapan, kebutuhan, dan pengalaman.

Para informan sebagai konsumen mengambil keputusan membeli dan menggunakan provider Telkomsel deipada Indosat dan XL tersebut melalui beberapa tahapan, yaitu sebagai berikut:

1) Pengenalan kebutuhan (needs recognition) untuk menggunakan Provider; proses pengambilan keputusan informan untuk membeli dan menggunakan 
produk tertentu, buatan perusahaan tertentu, atau dengan merek dagang tertentu dimulai sejak informan merasakan kebutuhan tertentu. Rasa membutuhkan provider tersebut dapat terangsang menjadi dorongan membeli produk apabila mendapat pengaruh dari dalam atau dari luar informan.

2) Penilaian berbagai macam informasi yang terkumpul (alternative evaluation); informan menggunakan informasi produk yang mereka kumpulkan sebagai bahan pertimbangan dalam memilih. Keputusan pemilihan produk dengan merek tertentu juga mengikuti suatu proses. Sebelum menjatuhkan pilihan, informan menilai keunggulan atribut suatu produk yang datanya telah mereka kumpulkan. Langkah berikutnya dari beberapa merek produk yang masih diminati, informan menentukan atribut yang paling cocok dengan keinginan mereka.

3) Keputusan membeli (purchase decision); apabila tidak ada faktor lain yang mempengaruhi, informan membeli produk dengan merek yang menjanjikan paling banyak atribut, yang sesuai dengan kebutuhan dan keinginan mereka. Akan tetapi, sering pada saat informan akan memutuskan pembelian muncul faktor-faktor yang menghambat keputusan pembelian.

4) Evaluasi setelah pembelian (post purchase evaluation); evaluasi informan pasca pembelian mempunyai arti penting bagi produsen. Seperti dengan adanya SMS Survei, sangat membantu produsen untuk feedback fitur-fitur yang mereka pasarkan kepada informan. Pengalaman informan mengonsumsi produk (positif atau negatif) berpengaruh dalam pengambilan keputusan membeli lagi produk yang sama pada saat mereka membutuhkannya lagi. Kesediaan informan membeli kembali produk merupakan salah satu sarana yang diperlukan perusahaan untuk mempertahankan kegiatan bisnisnya.

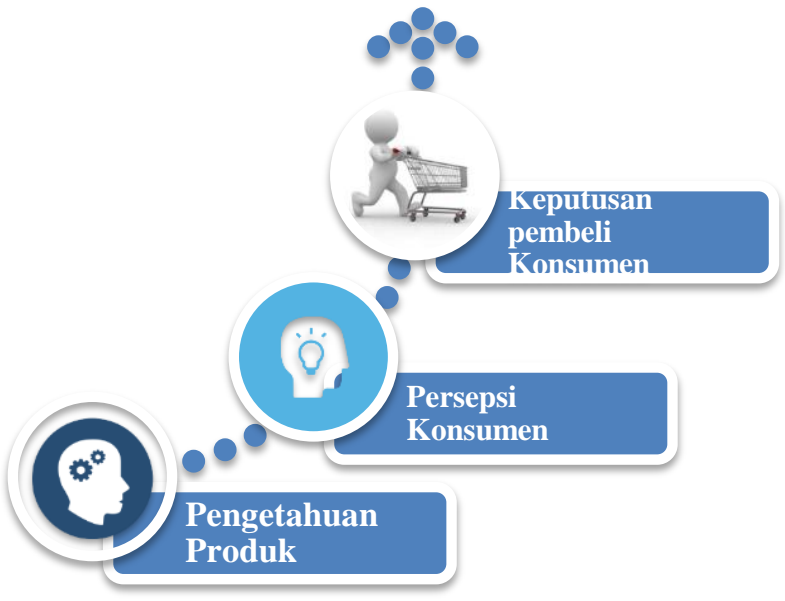

Bagan 1.2 Kerangka Konseptual Pertimbangan Konsumen Memilih Provider

Menurut Vinna Sri Yuniarti, S.E., M.M. (Perilaku Konsumen Teori dan Praktek, 2015: 30) menjelaskan bahwa pemenuhan kebutuhan memang penting 
untuk mengantarkan individu pada kehidupan yang selaras dengan lingkungannya. Pada umumnya, setiap orang akan melakukan kegiatan konsumsi dan menyenangi terhadap hal-hal yang bersifat konsumtif, seperti kegemaran berbelanja. Vinna juga mengutip pendapat Chumidatus Sa'diyah (2007) menjelaskan dalam ilmu ekonomi konsumsi ini merupakan kegiatan manusia yang mengurangi atau menghabiskan guna barang atau jasa yang ditunjukkan langsung untuk memenuhi kebutuhan hidupnya. Dan untuk Maria Magdalena dapat peneliti aplikasikan mengenai perilaku konsumtif yang gemar mengoleksi nomor cantik. Vinna (2015: 30-31) menjelaskan jika perilaku individu bersifat konsumtif maka tindakan membeli barang yang ia lakukan kurang atau tidak diperhitungkan sehingga sifatnya menjadi berlebihan.

Yang dimaksudkan oleh penulis mengenai pola perilaku konsumtif adalah pola pembelian dan pemenuhan kebutuhan yang lebih mementingkan faktor keinginan daripada kebutuhan dan cenderung dikuasai hasrat keduniawian dan keinginan semata. Gejala hasrat ini berhubungan dengan gerak dan perbuatan yang berpusat pada kejasmanian. (Drs. Abu Ahmadi dan Drs. M. Umar M.A., Psikologi Umum edisi revisi, 1982: 71)

Untuk motif pembelian provider berkaitan dengan waktu dan uang yang dihabiskan selama melakukan kegiatan tersebut. Motif belanja yang dilakukan oleh Maria Magdalena dan Fauziyah mempengaruhi pembelian aktual. Jika membahas mengenai pembelian aktual maka hal ini berkaitan dengan loyalitas mereka terkait dengan provider yang mereka gunakan. Misalnya untuk nomer simpati yang merupakan salah satu produk dari Telkomsel. Kartu ini ada masa aktif dan masa tenggang begitupula dengan provider yang lain. Masa aktif yang dimaksudkan disini adalah ketika Maria Magdalena dan Fauziyah masih dapat melakukan panggilan keluar ataupun panggilan masuk (telpon). Selain itu mereka juga dapat melakukan pengiriman dan penerimaan SMS, serta aktivasi paket Internet. Akan tetapi ketika informan memasuki masa tenggang, maka panggilan keluar dan mengirim SMS tidak dapat mereka lakukan. Mereka harus melakukan pembelian atau pengisian pulsa terlebih dahulu untuk menambah masa aktifnya baru untuk Telpon, SMS dan mengaktifkan paket Internet bisa mereka lakukan. Infroman hanya dapat menerima panggilan masuk saja bukan panggilan keluar jika memasuki masa tenggang. Dan jika informan sudah melewati masa tenggang maka kartu provider tersebut akan hangus dan tidak bisa dipergunakan kembali.

Membahas mengenai loyalitas pelanggan dapat kita telaah kembali dari pernyataan yang informan sampaikan bahwa Maria Magdalena sudah menggunakan provider \pm 10 tahun dan Fauziyah \pm 5 tahun. Informan melakukan pembelian produk Telkomsel secara berulang, yaitu melakukan isi ulang pulsa yang bukan hanya digunakan untuk menambah masa aktif kartu mereka saja, akan tetapi juga mereka gunakan untuk pembelian paket Telpon, SMS dan pembelian paket Internet. 
Keputusan informan membeli provider yang mereka gunakan saat ini adalah karena dari segi harga dan kualitas masing-masing provider. Informan akan memilih harga yang ekonomis dan memilih hal yang praktis. Ekonomis dan praktis dapat dilihat dan didengar dari pernyataan Maria Magdalena yang tidak peduli dengan adanya kuota malam. Kuota yang dipilih adalah kuota yang bisa dipakai 24 jam dan kuota yang harganya lebih murah. Sedangkan untuk Fauziyah lebih kepada kepastian kuota yang didapat dan kualitas signal yang bisa dipergunakan di lokasi dimana ia berada yaitu daerah Lumajang.

Menurut Onong Uchajana Effendi (Ilmu Teori dan Filsafa komunikasi, 2003), Jika dianalisa menggunakan stimulus respon (SOR) ini, maka efek yang ditimbulkan adalah reaksi khusus terhadap stimulus, sehingga informan dapat mengaharapkan dan memperkirakan kesesuaian antara pesan dan reaksi apa yang harus mereka lakukan yaitu berupa tanggapan positif dengan tetap loyal pada produk Telkomsel dan tanggapan negatif yaitu dengan menggunakan produk selain dari provider Telkomsel. Jadi unsur-unsur dari model ini adalah: Pesan (stimulus,S) bisa berupa iklan provider baik itu melalui media massa, cetak, dan sebagainnya lalu diterima oleh komunikan (Organism, O) atau informan baik itu Maria Magdalena dan Fauziyah. Dimana pada tahapan ini, informan akan melakukan perhatian, pengertian, penerimaan pesan tersebut, lalu timbulah efek (respon, R) seperti perubahan sikap membeli ataupun tidak membeli provider yang diiklankan. Sikap yang dimaksudkan oleh Effendi mengandung aspek evaluatif artinya mengandung nilai menyenangkan atau tidak menyenangkan ketika menggunakan suatu produk, dan yang dimaksudkan peneliti disini adalah provider Telkomsel, Indosat dan juga XL.

\section{SIMPULAN DAN SARAN}

Dari studi kasus pertimbangan konsumen memilih provider Telkomsel daripada Indosat dan XL, peneliti dapat menyimpulkan bahwa Maria Magdalena dan Fauziyah, kedua informan tersebut tidak sebegitu memanfaatkan informasi yang disampaikan oleh media massa karena peran gender yaitu kesibukan yang mereka lakukan. Dari mulai peran ibu rumah tangga, mahasiswa, dan sebagai wanita karir.

Teori uses and gratifications ini melihat kedua informan sebagai pemilik kehendak bebas. Mereka dapat menentukan kehendak bebas yang mereka miliki maka mereka dapat menentukan sendiri apakah pesan dari media massa berupa selective expossure, attentions, defense ataupun pesan media yang mereka blocking. Akan tetapi karena faktor peran gender tersebut, lantas mereka mimilih tetap menggunakan provider Telkomsel karena motif yang mereka miliki berupa kepuasaan koleksi nomer cantik untuk Maria Magdalena dan harga ekonomis serta kualitas signal dari provider Telkomsel untuk Fauziyah. Kedua informan samasama melakukan blocking iklan dari media televisi. 
Jika dianalisa menggunakan Stimulus Organism Respon (SOR) ini, apapun motif yang dimiliki oleh Maria Magdalena dan Fauziyah, kedua informan bukan lebih banyak mendapatkan stimulus dari media massa. Seperti yang penulis sampaikan sebelumnya bahwa kenyataanya para informan lebih banyak mendapatkan stimulus dari orang terdekat yaitu suami, teman dan counter (lokasi terdekat dimana para informan tinggal) yang merekomendasikan provider Telkomsel, Indosat dan XL kepada mereka.

Jadi, saran yang bisa peneliti sampaikan adalah karena konsumen sangat aktif mengenai kemajuan teknologi dan komunikasi. Apalagi televisi bukan satusatunya sarana untuk para pemasar provider. Maka untuk para pemasar harus lebih aktif mencari tahu kebutuhan konsumen agar produk yang mereka tawarkan dapat terus dipergunakan dan dipilih oleh konsumen (loyal). Promo memang memiliki andil dalam mempengaruhi konsumen dalam pembelian akan teatpi dengan harga dan kuota yang lebih setabil serta didukung dengan jaringan yang kuat (signal) maka konsumen akan lebih loyal kepada provider yang mereka pergunakan.

Agar iklan-iklan dari provider tersebut menarik perhatian pengguna, maka harus didapatkan karakter yang kuat dari provider sebagai pembeda produk mereka dengan produk yang lain. Perhatian pemasar ke konsumen juga dapat meningkatkan kepercayaan konsumen. Sehingga dapat disimpulkan bahwa untuk jumlah kuota, harga dan jumlah BTS (signal) juga menjadi bahan pertimbangan bagi informan dalam memilih provider Telkomsel, Indosat dan XL.

\section{DAFTAR PUSTAKA}

Azwar, Saifuddin. 1995. Sikap Manusia Teori Dan Pengukurannya. Yogyakarta: Pustaka Belajar.

Dewi, Irra Chisyanti. 2015. Pengantar Psikologi Media. Jakarta: Prestasi Pustaka Publisher.

Hall, Calvin S. 2000. Libido Kekuasaan Sigmund Freud. Yogyakarta: Tarawang Press.

Jaenudin, Ujam. 2012. Psikologi Kepribadiani. Bandung: CV Pustaka Setia.

Joseph, Thomas. 2011. Apps The Spirit of Digital Marketing 3.0. Jakarta: PT Gramedia.

Kanuk, Leslie Lazar dan Leon Schiffman. 2008. Perilaku Konsumen Edisi Ketujuh. Indonesia: PT Macanan Cahaya Cemerlang.

Kasali, Rhenald. 2011. Cracking Zone Bagaimana Memetakan Perubahan Di Abad

Ke 21 \& Keluar Dari Perangkap Comfort Zone. Jakarta: PT Gramedia Pustaka Utama.

Moleong, Lexy J. 2002. Metodologi Penelitian Kualitatif. Bandung: Remaja Rosdakarya. 
Mulyana, Deddy. 2003. Komunikasi Suatu Pengantar. Bandung: PT Remaja Rosdakarya. . 2007. Komunikasi Suatu Pengantar. Bandung: PT Remaja Rosdakarya.

Narbuko, Drs. Cholid dan Drs. H. Abu Achmadi. 2009. Metodologi Penelitian. Jakarta: Bumi Aksara.

Nurudin. 2010. Sistem Komunikasi Indonesia. Jakarta: RajaGrafindo Perkasa. . 2007. Pengantar Komunikasi Massa. Jakarta: RajaGrafindo Perkasa.

Rakhmat, Jalaluddin. Psikologi Komunikasi Edisi Revisi.

Sambas, Syukriadi. 2015. Sosiologi Komunikasi. Bandung: CV Pustaka Setia.

Sami'an, dkk. 2004. Insan Media Psikologi. Surabaya: Fakultas Psikologi Universitas Airlangga.

Sugiyono. 2014. Metodologi Penelitian Kuantitatif Kualitatif dan R\&D. Bandung: Alfabeta.

Suprapto, Tommy. 2011. Pengantar Ilmu Komunikasi. Yogyakarta: Caps

Umar, M. Dan Abu Ahmadi. 1982. Psikologi Umum Edisi Revisi. Surabaya: PT Bina Ilmu.

Yuniarti, Vinna Sri. 2015. Perilaku Konsumen Teori dan Praktek. Bandung: Pustaka Setia. 